Archives of Agriculture and Environmental Science

\title{
Water quality of River Ganga with reference to physico-chemical and microbiological characteristics during Kanwar Mela 2017, at Haridwar, India: A case study
}

\author{
Vinod Kumar ${ }^{1 *}$, Sanjay Kumar ${ }^{2}$, Sachin Srivastava ${ }^{3}$, Jogendra Singh ${ }^{1}$ and Pankaj Kumar ${ }^{1}$ \\ ${ }^{1}$ Department of Zoology and Environmental Science, ${ }^{2}$ Department of Botany and Microbiology, Faculty of Life Sciences, Gurukula \\ Kangri Vishwavidyalaya Haridwar-249404 (Uttrakhand), INDIA \\ ${ }^{3}$ Department of Agriculture and Forestry, Roorkee Institute of Technology, Roorkee-247667 (Uttarakhand), INDIA \\ "Corresponding author's E-mail: drvksorwal@gmail.com
}

\section{ARTICLE HISTORY}

Received: 22 December 2017

Revised received: 18 February 018

Accepted: 25 February 2018

\section{Keywords}

Ganga river

Heavy metals

Kanwar Mela

Microbiological parameters

Water quality

\section{ABSTRACT}

The present investigation was conducted to study the water quality of river Ganga during Kanwar Mela 2017 with reference to physico-chemical and microbiological characteristics at Haridwar city. Five sampling sites viz., Har ki Pauri (HKP), Vishnu Ghat (VG), Daksh Mandir (DM), Pul Jatwara (PJ) and Bhimgoda Barrage (BGB as control) were selected for collection of water samples. The reseult revealed that among the different sampling sites, the maximum values of EC $\left(0.164 \mathrm{dS} \mathrm{m}^{-1}\right)$, TS (545 $\left.\mathrm{mg} \mathrm{L}^{-1}\right)$, TDS (320 $\left.\mathrm{mg} \mathrm{L}^{-1}\right)$, TSS (225 mg L $\left.\mathrm{m}^{-1}\right), \mathrm{pH}$ (8.76), DO (10.04 mg L-1), BOD (4.76 mg L-1), COD (6.89 $\left.\mathrm{mg} \mathrm{L}^{-1}\right), \mathrm{Cl}^{-}\left(124.50 \mathrm{mg} \mathrm{L}^{-1}\right)$, Hardness (232.54 $\mathrm{mg} \mathrm{L}^{-}$ $\left.{ }^{1}\right)$, Alkalinity $\left(158.36 \mathrm{mg} \mathrm{L}^{-1}\right), \mathrm{NO}_{3}{ }^{2-}\left(76.88 \mathrm{mg} \mathrm{L}^{-1}\right), \mathrm{SO}_{4}{ }^{2-}\left(228.34 \mathrm{mg} \mathrm{L}^{-1}\right), \mathrm{SPC}\left(6.8 \times 10^{6} \mathrm{SPC} \mathrm{ml}{ }^{-1}\right)$,

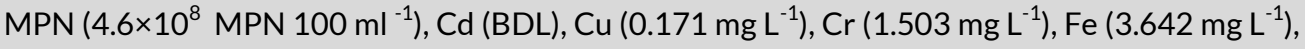
$\mathrm{Ni}(\mathrm{BDL})$ and $\mathrm{Zn}\left(2.456 \mathrm{mg} \mathrm{L}^{-1}\right)$ of Ganga River water were recorded higer at Har ki Pauri (HKP) in comparison to Vishnu Ghat (VG), Daksh Mandir (DM), Pul Jatwara (PJ) and Bhimgoda Barrage (BGB) sampling sites. Therefore, it was concluded from the present investigation that the mass bathing and relegious activities greatly influenced the water quality of River Ganga and significantly contributed to the water pollution of River Ganga during the Kanwar Mela 2017.

(C)2018 Agriculture and Environmental Science Academy

Citation of this article: Kumar, V., Kumar, S., Srivastava, S., Singh, J. and Kumar, P. (2018). Water quality of River Ganga with reference to physico-chemical and microbiological characteristics during Kanwar Mela 2017, at Haridwar, India: A case study. Archives of Agriculture and Environmental Science, 3(1): 58-63 DOI: 10.26832/24566632.2018.030108

\section{INTRODUCTION}

India has a unique place due to its religious, political, historical, geographical, environmental, socio-cultural, and as an emerging economic power not only in South Asian Countries, but also in the world (Yasir and Srivastava, 2016). Almost all the communities as Hindus, Muslims, Sikh and Christians are lived together and celebrated their auspicious events of happiness and sorrows together. Festivals has important place in human life as they bring lots of delight, enjoy and also social harmony. India is a land of festivals, parvas, melas and mahotsavas. Among festivals Deepawali, Holi, Nav Durga, Ganga Dashehara, Id-Ul-Fitre and Christmas is being celebrated by the native communities of India (Kamboj, 2012; Kamboj et al., 2017).

Haridwar is a holy city and municipal board in the Haridwar
District of Uttarakhand State, India. In Hindi, Haridwar ('Hari' meaning god and 'dwar' meaning gate) stands for Dwar of Hari or Gateway to God. Haridwar is regarded as one of the seven holiest places to Hindus (Charles, 1903; Rupinder and Reeta, 2004). Haridwar is one of the first towns where Ganga emerges from the Gangotri glacier in Himalayan Mountains to touch the plains. The water in the river Ganga is mostly clear and generally cold, except in the rainy season, during which soil from the upper regions flows down into it. Being a place of intense religious significance, Haridwar also hosts several religious festivals, Melas (fairs) throughout the year; popular among them are the Maha Kumbh, Ardha Kumbh, Kavar Mela, Somvati Amavasya Mela, Ganga Dashara, and Gughal Mela, in which around millions of people take part. The spot where the nectar fell is considered to be the Brahma Kund at Har ki Pauri 
(literally, "footsteps of the Lord," and symbolically the footprints of the Amrita), the most sacred ghat of Haridwar; thousands of devotees and pilgrims flock here during festivals or snan (Bath) from all over India and abroad to take a holy dip. Har ki Pauri, Vishnu Ghat, Chandi Devi Temple, Mansa Devi Temple, Maya Devi Temple, Daksha Mahadev Temple, Neel Dhara Pakshi Vihar, Sati Kund, Bhimgoda Tank, Jairam Ashram, Sapt Rishi Ashram and Sapt Sarovar, Parad Shivling, Ramanand Ashram, Prem Nagar Ashram, Ram Mandir, Doodhadhari Barfani Temple, Sureshvari Devi Temple, Paavan Dham, Bharat Mata Mandir, Anandamayi Ma Ashram, Piran Kaliyar are important religious places of Haridwar (Rupinder and Reeta, 2004). Celebration of festivals has great importance in Haridwar. As people of different religions and communities of national as well as foreign gathered here and take parts in celebration of festivals and in Haridwar. The festival Kanwar Mela is organized every year in the month of July in Haridwar and it is devoted for the worship of Almighty God Shiva. The pilgrims (Devotees of God Shiva) come to Haridwar, take holy bath in Ganga River and perform religious rituals and finally they return to their place with Ganga water (Ganga Jal) and offer it to the Shivlingam in the temple of God Shiva at their destinations (Charles, 1903; Rupinder and Reeta, 2004).

Rivers have a great importance and place in Indian civilization. These are considered as live entity and having a place as mother in the life of people in India. Ganga River is considered as most of the sacred river among different rivers in the country. People take baths in to the holy river and perform their rituals (Rizwan et al., 2016; Yasir and Srivastava, 2016). A number of tourist picnic spots and pilgrim centers and religious points have been established to perform various religious as well as recreational activities (Kumar and Chopra, 2012a,b,c; Kamboj, 2012; Kumar et al., 2016; Kamboj et al., 2017; Kumar and Thakur, 2017). During this, the quality of water of these rivers gets polluted severely. Therefore, most of the rivers in India are facing religious pollution due to the performance of heavy religious as well as recreational activities (Khullar and Khullar, 2004; Sati and Paliwal, 2008; Seth et al., 2016). The quality of Ganga River water is adversely polluted on the different occasions and celebrations of various festivals like holy bath, Kanwar Mela, Kumbh Mela and Ardhakumbha Mela etc. due to bathing of huge mass of pilgrims. The physico-chemical and microbiological characteristics of the Ganga River water has crossed the permissible or desirable limits (BIS, 2012) for almost all the parameters during these celebrations. The changes in the water quality in terms of physic-chemical and microbiological characteristics of a number of sacred rivers, lakes, streams, ponds (Kunds) and other water bodies have been reported by a number of researchers and suggested the regular monitoring of these water courses (Vega et al., 1998; Simeonov et al., 2003; Okendro et al., 2007; Jaji et al., 2007; Shamrukh and Abdel-Wahab, 2011; Brankov et al., 2012; Ilijević et al., 2012; Kansal et al., 2013; Haritash et al., 2016; Ghosh and Biswas, 2017; Oladeji, 2017; Takić Ljiljana et al., 2017). Therefore, regular monitoring of the water quality of these sacred water bodies is essential to maintain their ecological esthetic and recreational significance. Keeping in view the present case study was undertaken to assess the water quality of River Ganga with reference to physico-chemical and microbiological characteristics during Kanwar Mela 2017, at Haridwar, India.

\section{MATERIALS AND METHODS}

\section{Desription of sampling sites}

Haridwar city is situated under the Shivalik foot hills which is a part of Himalayan mountain chain. Haridwar is well connected by road to National Highway 58, between Delhi and Manapass. Nearest railway stations are at Haridwar, with direct links to all major cities of India. The nearest airport is Jolly Grant Airport, Dehradun, though Indira Gandhi International Airport, New Delhi. Five sampling sites viz., Har ki Pauri (HKP), Vishnu Ghat (VG), Dash Mandir (DM), Pul Jatwara (PJ) and Bhimgoda Barrage (BGB as Control) were selected for collection of Ganges water samples during Kanwar Mela 2017. The average distance between all these sites is about $2.5 \mathrm{~km}$. All these sites have an important place as per religious and recreational purposes in the city.

\section{Collection of samples and their analysis}

The Kanwar Mela is celebrated in the month of July every year. The devotees of God Shiva come to Haridwar and take holy bath in River Ganga and perform their religious activities. They took a holy dip in the river Ganga and worship the Goddess. The water samples of Ganga River from all five sampling sites were collected during the peak days of the Kanwar Mela. The samples were analyzed for various physico-chemical, microbiological and heavy metals viz., temperature, electrical conductivity (EC), total solids (TS), total dissolved solids (TDS), total suspended solids (TSS), $\mathrm{pH}$, dissolved oxygen (DO), biochemical oxygen demand (BOD), chemical oxygen demand (COD), chlorides (), hardness, alkalinity, nitrate $\left(\mathrm{NO}_{3}{ }^{2-}\right)$, sulphate $\left(\mathrm{SO}_{4}{ }^{2-}\right)$, cadmium $(\mathrm{Cd})$, copper $(\mathrm{Cu})$, chromium $(\mathrm{Cr})$, iron (Fe), manganese $(\mathrm{Mn})$, nickel (Ni), zinc $(\mathrm{Zn})$, standard plate count (SPC) and most probably number (MPN) following standard methods (APHA, 2012). For heavy metals analysis, $50 \mathrm{ml}$ sample of water was taken in digestion tube and add $10 \mathrm{ml}$ conc. $\mathrm{HNO}_{3}$ digest on electrically heated block for $1 \mathrm{~h}$ at $145^{\circ} \mathrm{C}$. Then add $5 \mathrm{ml}$ of $\mathrm{HClO}_{4}$ and heated to $240^{\circ} \mathrm{C}$ for an additional hour. Cool and filter through Whatman \# 42 filter paper and makeup volume 50 $\mathrm{ml}$ and was used for analysis of $\mathrm{Cd}, \mathrm{Cu}, \mathrm{Cr}, \mathrm{Fe}, \mathrm{Mn}, \mathrm{Ni}$ and $\mathrm{Zn}$ following standard methods (APHA, 2012).

\section{Statistical analysis}

Data were analyzed for one way analysis of variance (ANOVA) for determining the difference between water parameters before and after colour celebration and standard deviation, was calculated with the help of MS Excel 2016, SPSS12.0 and Sigma plot, 2000. 


\section{RESULT AND DISCUSSION}

\section{Physico-chemical characteristics of Ganga River water}

The physico-chemical characteristics of Ganga River water at different sampling sites viz., Har ki Pauri (HKP), Vishnu Ghat (VG), Daksh Mandir (DM), Pul Jatwara (PJ) and Bhimgoda Barrage (BGB) during Kanwar Mela-2017 at Haridwar are presented in Table 1.

\section{Water temperature}

During the present study, the temperature of the water was ranged $\left(18.40-18.42^{\circ} \mathrm{C}\right)$ at different sampling sites viz., Har ki Pauri (HKP), Vishnu Ghat (VG), Daksh Mandir (DM), Pul Jatwara $(\mathrm{PJ})$ and the temperature $\left(18.25^{\circ} \mathrm{C}\right)$ was slightly higher than the control site as Bhimgoda Barrage (BGB). Therefore, the temperature was recorded to be insignificantly $(P<0.05)$ different at different sampling sites (Table 1).

\section{Electrical conductivity}

Conductivity is the ability of a substance to conduct electricity. The conductivity of water is a more-or-less linear function of the concentration of dissolved ions. Conductivity itself is not a human or aquatic health concern, but because it is easily measured, it can serve as an indicator of other water quality problems. If the conductivity of a stream suddenly increases, it indicates that there is a source of dissolved ions in the vicinity. Therefore, conductivity measurements can be used as a quick way to locate potential water quality problems. In the present study the EC of the water was ranged $\left(0.156-0.164 \mathrm{dS} \mathrm{m}^{-1}\right)$ at different sampling sites viz., Har ki Pauri (HKP), Vishnu Ghat (VG), Daksh Mandir (DM), Pul Jatwara (PJ) and the temperature $\left(0.153 \mathrm{dS} \mathrm{m}^{-1}\right)$ was slightly higher than the control site as Bhimgoda Barrage (BGB). The EC was recorded to be insignificantly $(P<0.05)$ different at different sampling sites (Table 1$)$. Among different sampling sites, the value of EC $(0.164 \pm 0.04 \mathrm{dS}$ $\mathrm{m}^{-1}$ ) was recorded higher at Har ki Pauri (HKP) and it was likely due to the performance of more religious activities and bathing of huge crowd mass at Har ki Pauri (HKP) as it has religious and spiritual significance. The results of EC was in agreement with Kamboj (2012) who reported the changes in EC of water of river Ganga during Kanwer Mela-2011 at Haridwar, India

$\mathrm{pH}$

The $\mathrm{pH}$ is a measure of the amount of free hydrogen ions in water. Specifically, $\mathrm{pH}$ is the negative logarithm of the molar concentration of hydrogen ions. $\mathrm{A} \mathrm{pH}$ of 7 is considered to be neutral. Acidity increases as $\mathrm{pH}$ values decrease, and alkalinity increases as $\mathrm{pH}$ values increase. Most natural waters are buffered by a carbon-dioxide-bicarbonate system, since the carbon dioxide in the atmosphere serves as a source of carbonic acid. The $\mathrm{pH}$ of water affects the solubility of many toxic and nutritive chemicals; therefore, the availability of these substances to aquatic organisms is affected. As acidity increases, most metals become more water soluble and more toxic. The value of $\mathrm{pH}$ was recorded to be insignificantly $(P<0.05)$ different at different sampling sites during the study (Table 1 ). The $\mathrm{pH}$ of Ganga River water was recorded in the alkaline range (8.32-8.76) at different sampling sites and it was likely due to the use of detergents by the pilgrims during the holy bath.

\section{TS, TDS and TSS}

All natural waters contain some dissolved solids due to the dissolution and weathering of rock and soil. Suspended solids are determined by filtering a known volume of water and weighing the residue. Some but not the entire suspended solids act as conductors and contribute to turbidity. Waters with high total suspended solids (TSS) are unpalatable and potentially unhealthy. The values of TS, TDS and TSS was recorded to be significantly $(P>0.05)$ different at different sampling sites (Table 1). The values of TS (510-545 mg L $\left.{ }^{-1}\right)$, TDS (300-320 mg L ${ }^{-1}$ ) and TSS (210-225 mg L ${ }^{-1}$ ) were ranged at different sampling sites. Among different sampling sites the most values of TS (545 $\left.\mathrm{mg} \mathrm{L}^{-1}\right)$, TDS (320 mg L ${ }^{-1}$ ) and TSS (225 mg L ${ }^{-1}$ ) were observed at was recorded higher at Har ki Pauri (HKP) and it was likely due to the performance of more religious activities and bathing of huge crowd mass at Har ki Pauri (HKP). Rizwan et al. (2016) also reported the higher values of TS, TDS in the water of Lidder Stream at Pahalgam, (J\&K), India due to the excess tourism in Pahalgam, (J\&K).

\section{DO, BOD and COD}

Dissolved oxygen (DO) is the most important pollution assessment parameter of the receiving water bodies. Stabilization of organic matter, when discharged untreated or partially treated in receiving waters, leads to depletion of their DO. Nutrients (nitrogen and phosphorus) addition due to discharge of untreated or treated sewage may lead to algal growth in streams as a result depletion of DO in waters. Thus, it is observed that all the polluting constituents of sewage have their direct or indirect effect on DO of receiving waters. The impact of an effluent or wastewater discharge on the receiving water is predicted by its oxygen demand. This is because the removal of oxygen from the natural water reduces its ability to sustain aquatic life.

Biochemical oxygen demand (BOD) is a measure of the amount of oxygen that bacteria will consume while decomposing organic matter under aerobic conditions. The main focus of wastewater treatment plants is to reduce the BOD in the effluent discharged to natural waters. Wastewater treatment plants are designed to function as bacteria farms, where bacteria are fed oxygen and organic waste. The excess bacteria grown in the system are removed as sludge. If effluent with high BOD levels is discharged into a stream or river, it will accelerate bacterial growth in the river and consume the oxygen levels in the river. The oxygen may diminish to levels that are lethal for most fishes and many aquatic insects. Chemical oxygen demand (COD) is a vital test for assessing the quality of effluents and wastewaters prior to discharge. The COD test predicts the oxygen requirement of the effluent and is used for monitoring and control of discharges, and for assessing treatment plant performance. Thus, COD is a measure of the total quantity of oxygen required 
to oxidize all organic material into carbon dioxide and water.

During the present investigation the most values of BOD (4.76 $\mathrm{mg} \mathrm{L}^{-1}$ ) and COD (6.89 $\mathrm{mg} \mathrm{L}^{-1}$ ) were recorded at Har ki Pauri (HKP) and it was likely due to the performance of more religious activities and bathing of huge crowd mass at Har ki Pauri (HKP). While the value of DO (8.85 $\left.\mathrm{mg} \mathrm{L}^{-1}\right)$ was lower at Har ki Pauri (HKP) among different sampling sites (Table 1). The values of BOD (3.25-4.76 $\mathrm{mg} \mathrm{L}^{-1}$ ) and COD (6.52-6.89 $\mathrm{mg} \mathrm{L}^{-1}$ ) were ranged at different sampling sites viz., Har ki Pauri (HKP), Vishnu Ghat (VG), Daksh Mandir (DM), Pul Jatwara (PJ). The value of $D O$ was decreased while the values of $B O D$ and $C O D$ were increased at different sampling sites in comparison to the control site as Bhimgoda Barrage (BGB). The values of DO, BOD and COD were observed to be insignificantly $(P<0.05)$ different at different sampling sites (Table 1). Kamboj (2012) reported the variation in BOD, COD and DO at different sampling sites during Kanwar Mela, 2011 at Haridwar.

\section{Chloride, hardness and alkalinity}

Alkalinity is the capacity to neutralize acids, and the alkalinity of natural water is resulting mainly from the salts of weak acids. The carbonates, bicarbonates and hydroxide are the dominant source of natural alkalinity. Reactions of carbon dioxide with calcium or magnesium carbonate create considerable amounts of bicarbonates. Organic acids such as humic acid also form salts that increase alkalinity. Alkaline waters are unpalatable and can cause gastrointestinal discomfort. Nutrients such as phosphorous and nitrogen are essential for the growth of algae and other plants. Aquatic life is dependent upon these photosynthe- sizers, which usually occur in low levels in surface water. Excessive concentrations of nutrients, however, can over stimulate aquatic plant and algae growth.

In the present study, the values of chloride (118.36-124.50 mg L ${ }^{-1}$ ), hardness (221.00-232.54 $\mathrm{mg} \mathrm{L}^{-1}$ ) and alkalinity (146.37$158.36 \mathrm{mg} \mathrm{L}^{-1}$ ) was ranged at different sampling sites as Har ki Pauri (HKP), Vishnu Ghat (VG), Daksh Mandir (DM), Pul Jatwara (PJ) and these were insignificantly $(P<0.05)$ different to the control (Table 1). The most values of chloride (124.50 mg L ${ }^{-1}$ ), hardness (232.54 $\mathrm{mg} \mathrm{L}^{-1}$ ) and alkalinity (158.36 $\mathrm{mg} \mathrm{L}^{-1}$ ) were observed at Har Ki Pauri (HKP). Kumar and Chopra (2012c) reported the almost similar pattern of water characteristics of abandoned Old Ganga Canal at Haridwar (Uttarakhand) India.

$\mathrm{NO}_{3}{ }^{2-}$ and $\mathrm{SO}_{4}{ }^{2-}$

In the present study, the values of $\mathrm{NO}_{3}{ }^{2-}\left(73.00-76.88 \mathrm{mg} \mathrm{L}^{-1}\right)$ and $\mathrm{SO}_{4}{ }^{2-}\left(219.40-228.34 \mathrm{mg} \mathrm{L}^{-1}\right)$ was ranged at different sampling sites as Har ki Pauri (HKP), Vishnu Ghat (VG), Daksh Mandir (DM), Pul Jatwara (PJ) and these were found to be insignificantly $(P<0.05)$ different to the control (Table 1$)$. The most values of $\mathrm{NO}_{3}{ }^{2-}\left(76.88 \mathrm{mg} \mathrm{L}^{-1}\right)$ and $\mathrm{SO}_{4}{ }^{2-}\left(228.34 \mathrm{mg} \mathrm{L}^{-1}\right)$ were observed at Har ki Pauri (HKP).

\section{Heavy metals characteristics of Ganga River water}

The heavy metals are at very low concentrations in the natural environment, and they are typically introduced to surface waters as waste from human activities. Some of the metals of concern for human and aquatic health are cadmium, lead, copper, mercury, selenium, and chromium etc. The values of $\mathrm{Cu}$

Table 1. Water quality characteristics of river Ganga at different sampling sites during Kanwar Mela-2017 at Haridwar.

\begin{tabular}{|c|c|c|c|c|c|c|c|}
\hline \multirow{2}{*}{ Parameters } & \multirow{2}{*}{$\begin{array}{c}\text { BGB } \\
\text { (Control) }\end{array}$} & \multicolumn{4}{|c|}{ Sampling sites } & \multirow{2}{*}{$\begin{array}{c}\mathrm{F}- \\
\text { calculated }\end{array}$} & \multirow[t]{2}{*}{$C D$} \\
\hline & & HKP & VG & DM & PJ & & \\
\hline Temperature $\left({ }^{\circ} \mathrm{C}\right)$ & $18.25 \pm 1.23$ & $18.42 \pm 1.65$ & $18.41 \pm 2.89$ & $18.41 \pm 2.56$ & $18.40 \pm 1.58$ & $2.10^{\mathrm{NS}}$ & 0.05 \\
\hline$E C\left(d S m^{-1}\right)$ & $0.153 \pm 0.06$ & $0.164 \pm 0.04$ & $0.160 \pm 0.08$ & $0.158 \pm 0.07$ & $0.156 \pm 0.09$ & $0.03^{\mathrm{NS}}$ & 0.08 \\
\hline $\mathrm{TS}\left(\mathrm{mg} \mathrm{L}^{-1}\right)$ & $410 \pm 5.42$ & $545 \pm 2.56$ & $530 \pm 4.68$ & $515 \pm 2.58$ & $510 \pm 3.66$ & $3.22^{*}$ & 2.32 \\
\hline $\operatorname{TDS}\left(\mathrm{mg} \mathrm{L}^{-1}\right)$ & $280 \pm 3.21$ & $320 \pm 2.77$ & $310 \pm 2.54$ & $305 \pm 3.65$ & $300 \pm 2.58$ & $2.11^{*}$ & 1.09 \\
\hline $\operatorname{TSS}\left(\mathrm{mg} \mathrm{L}^{-1}\right)$ & $130 \pm 3.45$ & $225 \pm 1.25$ & $220 \pm 2.22$ & $210 \pm 3.21$ & $210 \pm 2.11$ & $1.09^{*}$ & 0.23 \\
\hline $\mathrm{pH}$ & $8.32 \pm 0.22$ & $8.76 \pm 0.55$ & $8.64 \pm 0.68$ & $8.62 \pm 0.14$ & $8.56 \pm 0.45$ & $2.19^{\mathrm{NS}}$ & 0.3 \\
\hline $\mathrm{DO}\left(\mathrm{mg} \mathrm{L}^{-1}\right)$ & $10.04 \pm 0.56$ & $8.85 \pm 1.24$ & $9.24 \pm 1.25$ & $9.75 \pm 1.03$ & $9.86 \pm 1.20$ & $0.05^{\mathrm{NS}}$ & 0.09 \\
\hline $\mathrm{BOD}_{5}$ at $20^{\circ} \mathrm{C}\left(\mathrm{mg} \mathrm{L}^{-1}\right)$ & $2.64 \pm 0.12$ & $4.76 \pm 0.12$ & $3.54 \pm 0.40$ & $3.32 \pm 0.36$ & $3.25 \pm 0.56$ & $0.21^{\mathrm{NS}}$ & 0.36 \\
\hline $\operatorname{COD}\left(\mathrm{mg} \mathrm{L}^{-1}\right)$ & $6.46 \pm 0.42$ & $6.89 \pm 0.88$ & $6.75 \pm 0.96$ & $6.64 \pm 0.94$ & $6.52 \pm 0.87$ & $0.06^{\mathrm{NS}}$ & 0.11 \\
\hline $\mathrm{Cl}^{-}\left(\mathrm{mg} \mathrm{L}^{-1}\right)$ & $117.12 \pm 0.44$ & $124.50 \pm 0.55$ & $122.63 \pm 0.65$ & $119.82 \pm 0.85$ & $118.36 \pm 0.75$ & $1.01^{\mathrm{NS}}$ & 1.09 \\
\hline Hardness $\left(\mathrm{mg} \mathrm{L}^{-1}\right)$ & $225.30 \pm 2.98$ & $232.54 \pm 1.64$ & $227.10 \pm 1.74$ & $224.45 \pm 1.85$ & $221.00 \pm 1.26$ & $1.06^{\mathrm{NS}}$ & 2.05 \\
\hline Alkalinity $\left(\mathrm{mg} \mathrm{L}^{-1}\right)$ & $145.55 \pm 3.46$ & $158.36 \pm 1.20$ & $152.37 \pm 2.56$ & $148.50 \pm 2.14$ & $146.37 \pm 2.52$ & $2.77^{\mathrm{NS}}$ & 3.28 \\
\hline $\mathrm{NO}_{3}^{2-}\left(\mathrm{mg} \mathrm{L}^{-1}\right)$ & $74.62 \pm 1.01$ & $76.88 \pm 0.21$ & $75.42 \pm 0.85$ & $73.68 \pm 1.21$ & $73.00 \pm 1.20$ & $0.21^{\mathrm{NS}}$ & 0.45 \\
\hline $\mathrm{SO}_{4}{ }^{2-}\left(\mathrm{mg} \mathrm{L}^{-1}\right)$ & $212.68 \pm 2.98$ & $228.34 \pm 1.23$ & $224.98 \pm 1.01$ & $220.36 \pm 1.14$ & $219.40 \pm 1.22$ & $2.14^{\mathrm{NS}}$ & 2.54 \\
\hline $\mathrm{Cd}\left(\mathrm{mg} \mathrm{L}^{-1}\right)$ & BDL & $\mathrm{BDL}$ & $\mathrm{BDL}$ & BDL & BDL & - & - \\
\hline $\mathrm{Cu}\left(\mathrm{mg} \mathrm{L}^{-1}\right)$ & $0.161 \pm 0.02$ & $0.171 \pm 0.01$ & $0.167 \pm 0.03$ & $0.165 \pm 0.01$ & $0.164 \pm 0.02$ & $0.06^{\mathrm{NS}}$ & 0.04 \\
\hline $\mathrm{Cr}\left(\mathrm{mg} \mathrm{L}^{-1}\right)$ & $1.500 \pm 0.03$ & $1.503 \pm 0.06$ & $1.503 \pm 0.06$ & $1.438 \pm 0.04$ & $1.434 \pm 0.05$ & $1.10^{\mathrm{NS}}$ & 1.06 \\
\hline $\mathrm{Fe}\left(\mathrm{mg} \mathrm{L}^{-1}\right)$ & $3.425 \pm 1.09$ & $3.642 \pm 1.20$ & $3.547 \pm 1.14$ & $3.536 \pm 1.07$ & $3.501 \pm 1.12$ & $1.01^{\mathrm{NS}}$ & 1.02 \\
\hline$M n\left(m g L^{-1}\right)$ & $0.610 \pm 0.03$ & $0.644 \pm 0.02$ & $0.638 \pm 0.04$ & $0.630 \pm 0.04$ & $0.627 \pm 0.01$ & $0.05^{\mathrm{NS}}$ & 0.03 \\
\hline $\mathrm{Ni}\left(\mathrm{mg} \mathrm{L}^{-1}\right)$ & BDL & BDL & BDL & BDL & BDL & - & - \\
\hline $\mathrm{Zn}\left(\mathrm{mg} \mathrm{L}^{-1}\right)$ & $2.348 \pm 0.12$ & $2.456 \pm 1.03$ & $2.421 \pm 1.02$ & $2.365 \pm 1.25$ & $2.354 \pm 1.01$ & $1.01^{*}$ & 0.02 \\
\hline $\mathrm{SPC}\left(\mathrm{SPC} \mathrm{ml}^{-1}\right)$ & $4.5 \times 10^{5} \pm 6.00$ & $6.8 \times 10^{6} \pm 6.00$ & $5.7 \times 10^{5} \pm 6.00$ & $5.5 \times 10^{5} \pm 6.00$ & $5.4 \times 10^{5} \pm 6.00$ & $4.26^{* *}$ & 3.59 \\
\hline MPN (MPN100 ml ${ }^{-1}$ ) & $3.2 \times 10^{8} \pm 7.00$ & $4.6 \times 10^{8} \pm 7.00$ & $3.8 \times 10^{8} \pm 7.00$ & $3.7 \times 10^{8} \pm 7.00$ & $3.5 \times 10^{8} \pm 7.00$ & $5.03^{* *}$ & 3.05 \\
\hline
\end{tabular}

Mean \pm SD of three values; BDL- below detection limit; CD- critical difference; Significant $F-{ }^{* *} P>0.1 \%,{ }^{*} P>5 \%$ level; NS- not significant; BGB- Bhimgoda barrage; HKP- Har Ki Pauri; VG-Vishnu Ghat; DM- Daksh Mandir; PJ- Pul Jatwara 
(0.164-0.171 $\left.\mathrm{mg} \mathrm{L}^{-1}\right), \mathrm{Cr}\left(1.434-1.503 \mathrm{mg} \mathrm{L}^{-1}\right)$, Fe (3.501-3.642 $\left.\mathrm{mg} \mathrm{L}^{-1}\right)$ and $\mathrm{Mn}\left(0.627-0.644 \mathrm{mg} \mathrm{L}^{-1}\right)$ were ranged and found to be insignificantly $(P<0.05)$ different at different sampling sites as Har ki Pauri (HKP), Vishnu Ghat (VG), Daksh Mandir (DM), Pul Jatwara (PJ) in comparison to control site (Bhimgoda Barrage BGB). The most values of $\mathrm{Cu}\left(0.171 \mathrm{mg} \mathrm{L}^{-1}\right), \mathrm{Cr}\left(1.503 \mathrm{mg} \mathrm{L}^{-1}\right)$, $\mathrm{Fe}\left(3.642 \mathrm{mg} \mathrm{L}^{-1}\right)$ and $\mathrm{Mn}\left(0.644 \mathrm{mg} \mathrm{L}^{-1}\right)$ were noted at Har ki Pauri (HKP) among different sampling sites. The values of $\mathrm{Cd}$ and $\mathrm{Ni}$ were noted below detection limit (BDL) at all the sampling sites (Table 1). Kumar and Chopra (2012b) reported the changes in heavy metals contents of sub canal of upper Ganga Canal at Haridwar (Uttarakhand), India due to the disposal of textile effluents in the upper Ganga Canal.

\section{Microbiological characteristics of Ganga River water}

Bacterial parameters, such as fecal coliform (FC) which serve as indicators of fecal pollution are also very important when human health is the prime concern. The specific identification of pathogenic bacteria is extremely difficult; the coliform group of organisms is used as an indicator of the presence in wastewater of pathogenic organisms. Coliform bacteria are found in intestinal tract of human beings. Coliform group of bacteria include genera Escherichia and Aerobacter. The values of SPC $\left(5.4 \times 10^{5}\right.$ $\left.6.8 \times 10^{6} \mathrm{SPC} \mathrm{ml}{ }^{-1}\right)$ and MPN $\left(3.5 \times 10^{8}-4.6 \times 10^{8} \mathrm{MPN} 100 \mathrm{ml}^{-1}\right)$ were ranged at different sampling sites as Har ki Pauri (HKP), Vishnu Ghat (VG), Daksh Mandir (DM), Pul Jatwara (PJ) and these were quite higher to the values of SPC $\left(4.5 \times 10^{5} \mathrm{SPC} \mathrm{ml}^{-1}\right)$ and MPN $\left(3.2 \times 10^{8} \mathrm{MPN} 100 \mathrm{ml}^{-1}\right)$ in comparison to control site (Bhimgoda Barrage BGB). Among different sampling sites the most values of SPC $\left(6.8 \times 10^{6} \mathrm{SPC} \mathrm{ml}^{-1}\right)$ and MPN $\left(4.6 \times 10^{8}\right.$ MPN100 $\mathrm{ml}^{-1}$ ) were observed at Har ki Pauri (HKP) and it is likely due to the mass bathing and to perform of various religious rituals at Har Ki Pauri (HKP). Kumar and Chopra (2012c) reported the higher values of SPC and MPN in the water of abandoned Old Ganga Canal at Piran Kaliyar, Haridwar due to the disposal of sewage effluent. Rizwan et al. (2016) also reported the changes in water quality characteristics of Lidder Stream at Pahalgam, (J\&K), India due to the excess tourism in Pahalgam, (J\&K).

\section{Conclusion}

It was concluded from the present study that the physicochemical and microbiological parameter of Ganga river water were varied at different sampling sites viz., Har ki Pauri (HKP), Vishnu Ghat (VG), Daksh Mandir (DM), Pul Jatwara (PJ) and was affected with the celebration of the festival of Kanwar Mela during 2017. Among different sampling sites, the maximum values of EC $\left(0.164 \mathrm{dS} \mathrm{m}^{-1}\right)$, TS $\left(545 \mathrm{mg} \mathrm{L}^{-1}\right)$, TDS (320 mg L$\left.{ }^{-1}\right)$, TSS (225 mg L$\left.{ }^{-1}\right), \mathrm{pH}$ (8.76), DO (10.04 $\mathrm{mg} \mathrm{L}^{-1}$ ), BOD (4.76 $\mathrm{mg} \mathrm{L}^{-}$ $\left.{ }^{1}\right), \mathrm{COD}\left(6.89 \mathrm{mg} \mathrm{L}^{-1}\right), \mathrm{Cl}^{-}\left(124.50 \mathrm{mg} \mathrm{L}^{-1}\right)$, Hardness (232.54 $\mathrm{mg} \mathrm{L}^{-}$ $\left.{ }^{1}\right)$, Alkalinity $\left(158.36 \mathrm{mg} \mathrm{L}^{-1}\right), \mathrm{NO}_{3}{ }^{2-}\left(76.88 \mathrm{mg} \mathrm{L}^{-1}\right), \mathrm{SO}_{4}{ }^{2-}(228.34$

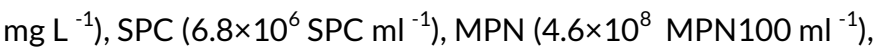
$\mathrm{Cd}$ (BDL), Cu (0.171 $\left.\mathrm{mg} \mathrm{L}^{-1}\right), \mathrm{Cr}\left(1.503 \mathrm{mg} \mathrm{L}^{-1}\right), \mathrm{Fe}\left(3.642 \mathrm{mg} \mathrm{L}^{-1}\right)$, $\mathrm{Ni}(\mathrm{BDL})$ and $\mathrm{Zn}\left(2.456 \mathrm{mg} \mathrm{L}^{-1}\right)$ of Ganga water were recorded higer at Har ki Pauri (HKP). The gathering of huge crowd mass and their active involvement in various religious and spritual activities significantly altered the physico-chemical and microbiological characteristics of the Ganga River water and therefore these alterations contributed the water pollution of Ganga River. Therefore, it is suggested from the present study, that the mass gathering and their activites must be checked and controlled through awareness among the pilgrims to prevent the holyness of the almighty Ganga River.

\section{ACKNOWLEDGEMENT}

Agriculture and Environmental Science Academy (AESA), Haridwar (Uttarakhand) India is acknowledged to privide the necessary facilities for conducting the present investigation.

Open Access: This is open access article distributed under the terms of the Creative Commons Attribution License, which permits unrestricted use, distribution, and reproduction in any medium, provided the original author(s) and the source are credited.

\section{REFERENCES}

APHA, (2012). Standard Methods for the Examination of Water and Wastewater. American Public Health Association, 23st edition, Washington, DC.

Brankov, J., Milijašević, D. and Milanović, A. (2012). The assessment of the surface water quality using the water pollution index: a case study of the Timok River (the Danube River basin), Serbia. Archives of Environmental Protection, 38(1): 49-61.

BIS, Bureau of Indian Standards (2012). Specification for drinking water. 1S: 10500, Bureau of Indian Standards, New Delhi.

Ghosh, D. and Biswas, J.K. (2017). Fish productivity: Assessing sustainability in a tropical oxbow lake of Nadia district, West Bengal, India. Archives of Agriculture and Environmental Science, 2(1): 6-20.

Haritash, A.K., Gaur, S. and Garg, S. (2016). Assessment of water quality and suitability analysis of river Ganga in Rishikesh, India. Applied Water Science, 6(4): 383-392, DOI: 10.1007/ s13201-014-0235-1

Ilijević, K., Gržetić, I., Živadinović, I. and Popović, A. (2012). Long -term seasonal changes of the Danube River eco-chemical status in the region of Serbia. Environmental Monitoring and Assessment, 184(5): 2805-2828.

Jaji, M.O., Bamgbose, O., Odukoya, O.O. and Arowolo, T.A. (2007). Water quality assessment of Ogun River, South West Nigeria. Environmental Monitoring and Assessment, 133(1): 473-482. DOI: 10.1007/s10661-006-9602-1

Kansal, A., Siddiqui, N.A. and Gautam A. (2013). Assessment of heavy metals and their interrelationships with some physico-chemical parameters in eco-efficient rivers of Himalayan Region. Environmental Monitoring and Assessment, 2013 185(3): 2553-63. DOI: 10.1007/s10661-012-2730-x 
Kamboj, N., Aswal, R.S. and Singh, P. (2017). Occurrence of heavy metals in Ganga canal water at Haridwar (Uttarakhand), India: A case study. Archives of Agriculture and Environmental Science, 2(2): 119-123.

Kamboj, N. (2012). Evaluation of some water quality parameters of river Ganga during Kanwer Mela-2011 at Haridwar, India. Journal of Sustainable Environmental Research, 1(2): 125-128.

Kumar, V. and Chopra, A.K. (2012a). Monitoring of physicochemical and microbiological characteristics of municipal wastewater at treatment plant, Haridwar (Uttarakhand) India. Journal of Environmental Science and Technology, 5 (2):109-118, DOI: 10.3923/jest. 2012.109.118

Kumar, V. and Chopra, A.K. (2012b). Effects of textile effluents disposal on water quality of sub canal of upper Ganga Canal at Haridwar (Uttarakhand), India. Journal of Chemical and Pharmaceutical Research, 4(9):4206-4211.

Kumar, V. and Chopra, A.K. (2012c). Hydrological characteristics of abandoned Old Ganga Canal at Haridwar (Uttarakhand) India. Journal of Chemical and Pharmaceutical Research, 4(11):4774-4782.

Kumar, V., Jogendra Singh, Roushan K. Thakur and Rohit Kumar (2016). Hydrobiological characteristics of pond water at Jamalpur Kalan, Haridwar (Uttarakhand), India. Journal of Environmental Science, Computer Science, and Engineering \& Technology, 5(3): 546-557.

Kumar, V. and Thakur R.K. (2017). Pollution load of SIDCUL effluent with reference to heavy metals accumulated in sediments using pollution load index (PLI) and geoaccumulation index (I-Geo) at Haridwar (Uttarakhand), India. Journal of Environment and Biosciences, 31(1): 163168.

Okendro, S.N., Surinder, K., Mahantpal, P.C., Pande, M.K. and Gopimohon, S.N. (2007). Evaluation of water quality from Gaula River by factor analysis. Journal of Ecophysiology and Occupational Health, 7: 3-4.

Oladeji, S.O. (2017). Evaluation of nickel levels in wastewater, soil and vegetable samples grown along Kubanni stream channels in Zaria, Kaduna State, Nigeria. Archives of Agriculture and Environmental Science, 2(3): 141-147.

Rizwan Mudathir Khandi and Sachin Srivastava (2016). Impact of tourism on water quality characteristics of Lidder Stream at Pahalgam, (J\&K), India. Archives of Agriculture and Environmental Science, 1(1): 37-42.

Khullar, R. and Khullar, R. (2004). Gateway to the Gods: Haridwar-Rishikesh. UBS Publishers ISBN 8174764607.

Sati, S. and Paliwal, P.C. (2008). Physico-chemical and bacteriological analysis of Kosi River Water Central Himalaya. Pollution Research, 27(1): 179-183.

Seth, R., Mohan, M., Singh, P., Singh, R., Dobhal, R., Singh, K.P. and Gupta, S. (2016). Water quality evaluation of Himalayan Rivers of Kumaun Region, Uttarakhand, India. Applied Water Science, 6(2): 137-147, DOI: 10.1007/s13201-0140213-7

Simeonov, V., Stratis, J.A., Samara, C., Zachariadis, G., Voutsa, D., Anthemidis, A., Sofoniou, M. and Kouimtzis, T. (2003). Assessment of the surface water quality in northern Greece. Water Research, 37(17): 4119-4124, doi.org/10.1016/ S0043-1354(03)00398-1.

Shamrukh, Mohamed and Abdel-Wahab, Ahmed (2011). Water pollution and riverbank filtration for water supply along River Nile, Egypt. In: Riverbank Filtration for Water Security in Desert Countries, 5C. Ray and M. Shamrukh (eds.), pp: 125, DOI 10.1007/978-94-007-0026-0_2

Takić Ljiljana, Ivana Mladenović-Ranisavljević, Dejan Vasović and Ljiljana Đorđević (2017). The assessment of the Danube River water pollution in Serbia. Water, Air and Soil Pollution, 228: 380, DOI: 10.1007/s11270-017-3551-x

Vega, M., Pardo, R., Barrado, E. and Deban, L. (1998). Assessment of seasonal and polluting effects on the quality of river water by exploratory data analysis. Water Research, 32: 3581-3592.

Yasir and Srivastava, S. (2016). Monitoring of ground water quality in the province of district Dehradun, (Uttarakhand), India. Archives of Agriculture and Environmental Science, 1(1): 43-48. 